\title{
The Potential of Sport Development with Quality Control Physical Education Program
}

\author{
Said Junaidi ${ }^{1}$, Fajar Awang Irawan ${ }^{2}$, Sri Sumartiningsih ${ }^{3}$, Agus Darmawan $^{4}$ \\ \{said.ikor@mail.unnes.ac.id ${ }^{1}$, fajarawang@mail.unnes.ac.id ${ }^{2}$,sri.sumartiningsih@ @ail.unnes.ac.id ${ }^{3}$ \} \\ Universitas Negeri Semarang, Semarang, Indonesia ${ }^{1,2,3}$
}

\begin{abstract}
The research objective to analyze the relevance and quality of the content of physical education learning materials with the basic motor skills of sports coaching. This type of research is descriptive qualitative. The research subjects were Physical Education Teachers and Sports Trainers. The research instrument used a questionnaire and data analysis techniques with a qualitative analysis approach. The results of the study, the learning material is less relevant to the basic concepts of sports development. Material development is less oriented towards the needs of basic sports movements. Learning management is not supportive of children's motor potential for sports development. The quality and content of the material do not yet support children's motor skills as the basis for sports development. There is no quality control document in the form of guidelines for developing and managing materials, guidelines for motion analysis, guidelines for measuring basic motion, and guidelines for guiding sports talents.
\end{abstract}

Keywords: Physical Education, Quality Control, Sports Development.

\section{Introduction}

Sport contributes to developing the values of sports by producing quality human resources. Sports coaching is part of developing the quality of Indonesian people to improve health, fitness, mental, personality and sportsmanship as well as increasing achievement for national pride (Jamalong, 2014).Sports as a guideline for the values of life become the basis for sports development at the next stage, namely the development of sports as recreation, sports as education, and sports for achievement. (Sirait et al., 2021).The development of sports with the aim of achievement is an important part of enhancing the dignity of the nation and contributing to enhancing the nation's image in the international world. Performance sports are able to provide a promotional function for the nation's existence in world competition.

The sports development system in Indonesia has experienced a significant decline, this is indicated by the decline in Indonesia's sports achievements in the activities of the Sea Games, Asian Games, Olympic Games as well as regional and international single event activities. The achievements in Southeast Asia, Asia and the world events are indicators of the weakness of the performance sports coaching system. This is because the coaching process is not sustainable at every stage of coaching. The occurrence of discontinuity in the regeneration system in training athletes causes regeneration to be hampered. Therefore an alternative tiered coaching system is needed starting from an early age through physical education media in schools (Said Junaidi, 2019) 
Achievement sports development system is carried out through various strategies so as to produce high and consistent performance products. Performance sports development is a nursery system that engages athletes with achievement goals. (Rudiansyah et al. 2017). The performance sports development system can be carried out through several stages and each stage must have relevance to the next stage so that collaborative synergy occurs. Coaching can be carried out by empowering sports clubs, developing national and regional sports coaching centers and carrying out tiered and sustainable competitions (Wibowo \& Hidayatullah, 2017).

The phases in the coaching system can be carried out from multilateral development stages to high achievement by applying the pyramid model concept. The pyramid model coaching positions physical education activities at the lower level, namely the phase to develop children's physical and motor capacities in general. Physical learning is considered as an effective medium to instill the basics for physical and motor development in children. Measured and programmed physical and motor development will support the process of coaching athletes in the next phase. The next phase after the multilateral training stage is coaching to determine the potential for sports talents in groups of children who have talents and interests.

Physical education program as the basis for sports coaching is one of the potential alternatives to develop sports achievement. Schools have great potential in terms of stimulating the development of student motor skills (Ericsson, 2016). The model of training for sportsmen in schools has a very effective value, for forming high-achieving athletes and for recruiting prospective athletes. (Noor Akhmad, 2019). According to Enung (2006), in accordance with the development phase, good sports activities for students in physical education lessons are activities that have characteristics; (1) provide a variety of movement experiences (multilateral training) in the form of games and competitions; (2) stimulating the development of all five senses; (3) developing imagination / fantasy; and (4) moving to the rhythm / song and story (Hidayah, 2011).

The implementation of the physical education program has not been implemented as expected in supporting the sports coaching system. This is because the implementation of learning is still oriented towards conventional learning methods so that students do not have the opportunity to experience various skills. Previous research has shown that early childhood physical education has not been able to achieve the objective to develop the abilities of early childhood cognitive, affective and psychomotor (Pechtel \& Pizzagalli, 2011). This is because the learning process is still focused on the role of the teacher, and learning activities are still centered in the classroom. This condition results in children's learning feeling bored, so that the physical education being taught is less meaningful. (Sandey Tantra Paramitha, 2018)

\section{Methods}

This research design deals with what is understood, interpreted by the research subjects. (Burhan Bungin, 2011). Qualitative research can show people's life, history, and organizational functional behavior. (M. Djunaidi dan Fauzan A, 2012). Furthermore, this study is to obtain data on the behavior of the people being observed including descriptions and notes on the results of the interviews. The instrument used was an interview guide. The research focus is on the potential of sports coaching with quality control of physical education programs. The subjects of this study were elementary school physical education teachers and sports coaches. The data source comes from information on the physical education program 
teacher. The technique of collecting data by interview. Data analysis techniques through the stages of data condensation, data display, and conclusion drawing / verification.

\section{Result and Discussion}

The curriculum is designed by policy makers through a careful analysis process and according to student needs. In accordance with the applicable provisions that all teachers at all levels of school must have a learning program curriculum document and it must be implemented. All teachers have curriculum documents that are archived in the school administration system. The curriculum document is used as the basis for implementing learning programs carried out by teachers in schools. This is in accordance with the opinion which states that the curriculum is one of the most important components that determine the unit of the education system. The consequence is that implementers in schools must manage the curriculum well, so that the learning outcomes will be more effective (Thaib, Razali M., 2015). All physical education teachers have a curriculum document and are used as the basis for developing a learning program plan (RPS). In addition to curriculum documents, teachers have learning supporting documents, namely semester learning plans arranged based on the curriculum. Whereas for the RPS systematics it is compiled based on the material contained in the curriculum text and in accordance with the applicable guidelines at the elementary school level.

The scope of the material in the curriculum is arranged based on the basic competencies (KD) that are in the structure of the curriculum material. The teacher has carried out learning based on the Student Work Sheet (LKS) book. In the worksheets, materials that can be used by teachers as learning materials for physical education programs have been compiled. The material listed in the curriculum document according to the physical education teacher is in accordance with the child's ability level based on the grade level. The content of the curriculum material is arranged systematically based on the stages of students' abilities. The information obtained shows that some students can do the material presented by the teacher even though many of the students are inactive and do not do it right. The material presented in the physical education program is not all in accordance with the facilities owned by the school. Some schools do not have facilities and equipment in accordance with all the material listed in the curriculum document. Some materials must be modified according to the facilities owned. It is not uncommon for the material listed in the physical education manual not to be realized because it is not supported by the existing equipment and facilities at the school.

The material presented in the physical education learning program has only been oriented towards material attainment as listed in the LKS book without paying attention to the standards of motoric development for children. Material development is less oriented towards the needs of basic sports movements. Not all teachers do material analysis related to the effect of material on motor development. Some teachers implement material in the physical education curriculum without paying attention to the impact of accompanying motor development. Not all teachers have a standard of motor development which is expected to be part of sports coaching. The material presented is more focused on developing students' physical fitness. While theoretically the material for physical learning programs is not only for physical fitness but also for building children's motor skills. Good children's motor skills can prepare children for the next phase, namely the regeneration phase of sports for those who are gifted and have potential 
Some teachers do not have the motion analysis forms and tables that are needed in sports coaching. So that the material presented is limited to the implementation of the material in the curriculum. Some teachers do not have data to assess at each meeting whether the material being taught has a significant impact on children's motor development. There was no form found for material quality control in the learning process. The teacher does not carry out the process of observing students' motion There is no quality control document in the form of guidelines for developing and managing materials, guidelines for motion analysis, guidelines for measuring basic motion, and guidelines for guiding sports talents.

According to the sports coach, there is no strong link between the material of the Jasmai education program in elementary schools and the motor needs of children in developing sports. The material taught has not made a real contribution in developing the basic needs of motor sports. According to the sports coach, the standard of motor skills for nurseries has a higher level of difficulty, so the learning material should be increased in complexity according to the child's age level.

\section{Conclusion}

Schools and teachers have a curriculum text that is documented and used in the learning program. Learning through semester learning plans. The scope of the material is based on basic competencies. The material is in accordance with the child's ability and the content of the curriculum material is arranged systematically. Students can do the material and there are students who are not active and do not do it right. The material presented is not all in accordance with the facilities owned by the school. The material presented is oriented towards student worksheets. The standard of motoric development of children is not given enough attention Not all teachers conduct material analysis on motor development. Implementing the material without paying attention to the impact of the accompanying motor development. Teachers do not yet have a standard of motor development according to the needs of sports coaching. The material focuses more on developing students' physical fitness and does not yet have the goal of building children's motor skills. The teacher does not have the motion analysis form needed in sports coaching. Teachers do not have instruments to assess the impact of the material on children's motor development. There is no material quality control form in the learning process. According to the trainer, the material being taught has not made a real contribution in developing the basic needs of sports. The standard of sports nursery ability has a higher level of difficulty

\section{References}

[1] Burhan Bungin. (2011). Penelitian Kualitatif (Edisi Ke-2) Prenada Media Group. Jakarta. 77

[2] Hidyah, T. (2011). Latihan Multilateral Alternatif Untuk Meningkatkan Kondisi Fisik Pemain Bola Basket. Jurnal Media Ilmu Keolahragaan Indonesia, 1, 104-105.

[3] Ericsson, I. R. (2016). Research Articles Effects of motor skills training and daily physical education; Research results in the Swedish Bunkeflo project. International Journal of Physical Education, January 2014, 2.

[4] Jamalong, A. (2014). Dini melalui pusat pembinaan dan latihan pelajar ( pplp ) dan pusat pembinaan dan latihan mahasiswa. Jurnal Pendidikan Olah Raga, Vol. 3, No. 2, Desember 2014. $156-167$.

[5] M.Djunaidi dan Fauzan A. (2012). Metodologi Penelitian Kualitatif. Yogyakarta. Pen. Ar-Ruzz Media. 25 
[6] Noor Akhmad, F. Z. (2019). Potensi Prestasi Pengembangan Olahraga Unggulan Mataram. Jurnal Ilmu Sosail dan Pendidikan 3 (3), 57.

[7] Rudiansyah, E., Soekardi, \& Hidayah, T. (2017). Pembinaan Olahraga Prestasi Unggulan di Kabaputen Melawi Kalimatan Barat. Jurnal Pendidikan Jasmani Kesehatan dan Rekreasi (Penjaskesrek) Volume 4, Nomor 1, Januari 2017. 3

[8] Sirait, J., Noer, K. U. (2021). Implementasi Kebijakan Keolahragaan dan Peran Pemangku Kepentingan dalam Peningkatan Prestasi Atlet. JORPRES (Jurnal Olahraga Prestasi), 17 (1), 2021. 2

[9] Sandey Tantra Paramitha, L. E. A. (2018). Revitalisasi Pendidikan Jasmani untuk Anak Usia Dini melalui Penerapan Model Bermain Edukatif Berbasis Alam. Jurnal Pendidikan Jasmani Dan Olahraga, 3(1), 43. https://doi.org/10.17509/jpjo.v3i1.10612

[10] Said Junaidi. (2019). Pembangunan Olahraga Prestasi Di Jawa Tengah: Disertasi. Pascasarjana. Universitas Negeri Semarang. 111-112

[11] Thaib, Razali M., I. S. (2015). Inovasi Kurikulum Dalam Pengembangan Pendidikan (Suatu Analisis Implementatif). Jurnal Edukasi, 1(July), 216.

[12] Wibowo, K., \& Hidayatullah, M. F. (2017). Evaluasi Pembinaan Prestasi Olahraga Bola Basket di Kabupaten Magetan. Jurnal Media Ilmu Keolahragaan Indonesia. Volume 7. Nomor 1. Edisi Juni 2017. 10 